\title{
Permainan Outdoor dalam Membentuk Kemampuan Ketahanmalangan pada Anak Usia Dini
}

\author{
Ade Karunia Rizky Manurung ${ }^{1 凶}$, Sri Wulan², Agung Purwanto ${ }^{3}$ \\ Pendidikan Anak Usia Dini, Universitas Negeri Jakarta \\ DOI: $10.31004 /$ obsesi.v5i2.1030
}

\begin{abstract}
Abstrak
Kemampuan ketahanmalangan anak belum berkembang dengan baik secara optimal. Hal ini dapat terlihat dari permasalahan-permasalahan yang terlihat dalam kegiatan sehari-hari anak masih mudah menyerah saat menghadapi tantangan dan masalah yang ada. Penelitian ini bertujuan untuk mendeskripsikan permainan outdoor dalam membentuk kemampuan ketahanmalangan pada anak. Metode penelitian ini menggunakan pendekatan kualitatif dengan teknik studi literatur yang bersumber dari buku dan literatur-literatur terdahulu sesuai dengan topik penelitian. Teknik analisi data dalam penelitian ini terdiri dari tiga langkah yaitu, reduksi data, penyajian data dan menarik kesimpulan. Hasil menunjukkan bahwa melalui permainan outdoor dapat melatih dan membentuk kemampuan ketahanmalangan anak. Hal ini dikarenakan permainan outdoor dapat memberikan kegiatan belajar sambil bermain dengan diisi permainan-permainan yang menantang, berpetualang dan bebas yang berpengaruh dalam membentuk kepribadian, percaya diri, memecahkan masalah dan sikap tidak menyerah dalam diri anak yang termasuk dimensi kemampuan ketahanmalangan.
\end{abstract}

Kata Kunci: kemampuan ketahanmalangan; permainan outdoor; anak usia dini

\begin{abstract}
The adversity quotient the child has not been optimally developed. This can be seen from the problems seen in daily activities that young people cry when facing existing challenges and problems. This study aims to describegames outdoor in forming adversity quotient in children. This research method uses a qualitative approach with literature study techniques sourced from books and previous literatures in accordance with the research topic. The data analysis technique in this study consisted of three steps, namely, data reduction, data presentation and drawing conclusions. The results show that throughplay outdoor, it can train and form children's adversity quotient. This is becausegames outdoor can provide learning activities while playing with games that are challenging, adventurous and free which have an effect on shaping personality, self-confidence, solving problems and not giving up in children, including the dimensions of adversity quotient.
\end{abstract}

Keywords: adversity quotient; outdoor play; early childhood

Copyright (c) 2021 Ade Karunia Rizky Manurung, Sri Wulan, Agung Purwanto

$\triangle$ Corresponding author :

Email Address : adekarunia14@gmail.com (Medan, Indonesia)

Received 5 January 2021, Accepted 13 January 2021, Published 16 January 2021 


\section{PENDAHULUAN}

Belajar merupakan proses yang berlangsung sepanjang hayat, yang dimulai sejak anak lahir, dewasa, dan berakhir ketika meninggal dunia. Proses pembelajaran yang berhasil akan memberikan dampak positif terhadap pencapaian kemampuan-kemampuan yang ada dalam diri anak. Berbagai kemampuan yang dicapai oleh anak melalui proses kematangan dari perkembangan yang dilalui akan berpengaruh terhadap keterampilan hidup anak. Anak yang memiliki keterampilan hidup yang baik dalam dirinya maka perilaku positif akan terbentuk dalam diri anak saat anak menghadapi segala tantangan dalam hidup (UNICEF, 2003). Selain itu, anak yang memiliki keterampilan hidup yang baik akan dapat mengembangkan aspek perkembangan anak, salah satunya aspek perkembangan kemampuan ketahanmalangan (Azlina \& S., 2012). Maka dari itu, Kemampuan ketahanmalangan memiliki peran penting dalam keberhasilan kehidupan individu. Hal ini dikarenakan dalam sepanjang hidup individu akan mengalami sebuah proses adaptasi yang di dalamnya terdapat tantangan yang menuntut individu harus bertahan dalam proses adaptasi tersebut, sehingga kemampuan ketahanmalangan perlu ditanamkan sejak usia dini. Hal ini sejalan dengan pendapat Handini yang menyatakan bahwa kemampuan ketahanmalangan perlu dilatih sejak dini agar seorang individu dapat terampil dan terbiasa dalam menyelesaikan masalah sehari-harinya dalam menuju keberhasilan dan kesuksesan kehidupan dimasa yang akan datang (Crie Handini \& Nur Hasanah, 2017). Pendapat lain yang dikemukakan oleh Grotberg bahwa ketahanmalangan perlu dikembangkan sejak usia dini karena pada proses perkembangan dan pertumbuhan anak akan ditemukan berbagai masalah (Grotberg, 1995). Anak-anak yang memiliki kemampuan ketahanmalangan yang baik akan dapat menyelesaikan masalah dan trauma yang anak hadapi dalam lingkungan keluarga maupun lingkungan masyarakat. Hal ini yang membentuk anak akan menjadi individu yang dapat bertahan hidup dengan segala perubahan yang terjadi dalam hidup sampai anak beranjak dewasa.

Namun, dilapangan ditemukan beberapa permasalahan terkait kemampuan ketahanmalangan, seperti anak yang masih mudah menangis atau cengeng saat menghadapi sesuatu masalah. Anak belum dapat mengendalikan emosinya dengan baik terhadap keadaan yang anak alami (Agama Kementrian, 2020). Selanjutnya, (Holifatur \& Christiana, 2013) dalam penelitiannya menemukan masalah mengenai sikap anak yang manja yang mengakibatkan anak tidak mampu memecahkan masalah yang sedang anak hadapin dengan sendiri, sehingga menjadikan anak menjadi anak yang ketergantungan terhadap bantuan orang tua. Selanjutnya, dalam penelitian (Kuswanto, Wijaya, 2016) ditemukan juga permasalahan seperti anak kurang mampu dalam mengurus dirinya sendiri. Hal ini yang menjadikan anak masih bergantung kepada orang lain dalam melakukan sesuatu. Akibatnya, ketika anak dihadapkan oleh masalah dalam kehidupannya anak tidak dapat mengambil keputusan dan menyelesaikannya sendiri yang berdampak terhadap kemampuan ketahanmalangan anak.

Kemampuan ketahanmalangan bukan sesuatu yang diperoleh dengan instan. Namun, sesuatu yang dapat dilatih dan dibentuk. Dalam melatih dan membentuknya diperlukan keterlibatan orangtua, guru, masyarakat dan pendidikan yang ada di sekitar anak. Salah satu cara yang dapat dilakukan dalam meningkatkan kemampuan ketahanmalangan, yaitu melalui pendidikan anak usia dini. Proses pendidikan pada anak usia dini dikenal sebagai kegiatan bermain sembari belajar. Melalui kegiatan bermain secara tidak langsung anak usia dini akan dilatih dan dibentuk kemampuan-kemampuan yang terdapat dalam diri anak, seperti kemampuan ketahanmalangan anak. Hal ini sejalan dengan pendapat (Crie Handini \& Nur Hasanah, 2017) yang menyatakan bahwa keberhasilan pencapaian kemampuan ketahanmalangan pada individu dapat dilatih sejak usia dini melalui kegiatan bermain yang menyenangkan agar anak menjadi anak yang sukses di masa yang akan datang. 
DOI: $10.31004 /$ obsesi.v5i2.1030

Salah satu kegiatan permainan yang dapat membantu perkembangan ketahanmalangan pada anak, yaitu kegiatan permainan outdoor. Hal ini dikarenakan permainan outdoor dapat memberikan kegiatan pembelajaran yang secara langsung dilakukan di alam terbuka dengan memanfaatkan alam sekitarnya sebagai media pembelajaran. Kegiatan belajar sambil bermain dengan diisi permainan ketangkasan dalam usaha membentuk kepribadian, memantapkan permasalahan kepemimpinan untuk membentuk karakter anak, percaya diri dan sikap tidak menyerah dalam diri anak (Maynard et al., 2014). Selanjutnya, dalam penelitian (McFarland \& Laird, 2018) menyatakan bahwa permainan outdoor dapat membantu melatih keberanian dalam diri anak yang dapat mendorong perkembangan kemampuan ketahanmalangan. Selanjutnya, penelitian (Blanchet-Cohen \& Elliot, 2011) yang menyatakan bahwa permainan outdoor memberikan manfaat dalam mengembangkan rasa tanggung jawab dalam menyelesaikan tantangan dalam kehidupan anak. Salah satu kegiatan permainan outdoor yang berdampak terhadap kemampuan ketahanmalangan anak adalah permainan outbound. Hal ini dikarenakan dalam permainan outbound akan melatih kekuatan, kelincahan, keberanian dan ketangguhan (Sutapa et al., 2020). Pendapat lain dari (McFarland \& Laird, 2018) yang menyatakan bahwa melalui jenis permainan outbound akan memberikan kesempatan kepada anak untuk melewatin tantangan yang terdapat dalam permainan dan mendorong anak untuk mengambil keputusan yang membuat anak berhasil dalam permainan yang ada. Berdasarkan latar belakang tersebut, ditepeneliti akan menyajikan telaah dari beberapa literatur yang berkaitan dengan permainan outdoor dalam membentuk kemampuan ketahanmalangan pada anak usia dini.

\section{METODOLOGI}

Penelitian ini menggunakan metode penelitian studi literatur dengan menelaah beberapa literatur dari berbagai sumber artikel jurnal dan buku terkait permainan outdoor dan kemampuan ketahanmalangan untuk melihat apakah permainan outdoor dapat membanguan kemampuan ketahanmalangan pada anak usia dini. Penelitian ini penting dilakukan untuk memberikan informasi kepada pembaca bahwa kemamampuan ketahanmalangan merupakan salah satu kemampuan yang penting dibangun sejak usia dini dan dapat dibangun dengan kegiatan bermain, salah satunya adalah kegiatan bermain outdoor.

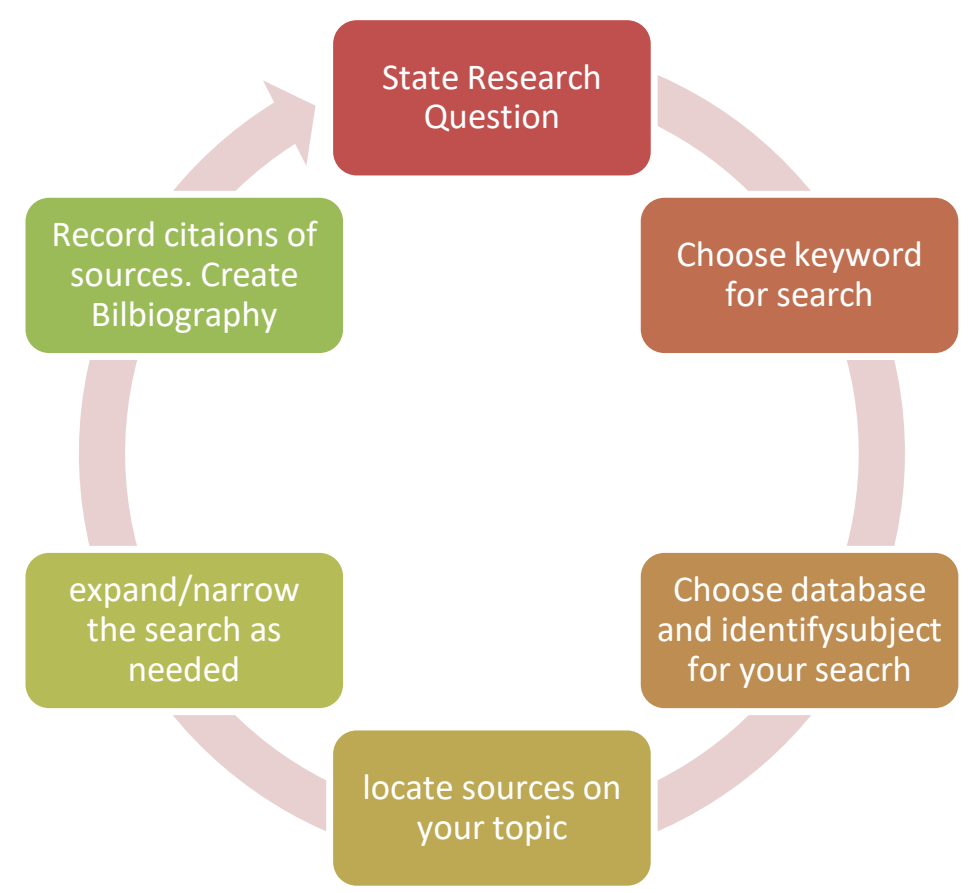

Gambar 1 Langkah-langkah penelitian studi literatur 
Instrumen dalam penelitian ini adalah peneliti itu sendiri (Woodrow \& Woodrow, 2019). Sumber data dalam penelitian ini adalah data sekunder, berupa literatur-literatur reveiw terdahulu yang sesuai dengan topik penulisan artikel ini yaitu, permainan outdoor dan kemampuan ketahanmalangan. Teknik pengumpulan data yang dilakukan adalah dokumentasi, yaitu pengumpulan catatan atau peristiwa yang didapat dari artikel atau sumber online lain yang sesuai dengan topik artikel. Hasil dari beberapa literatur yang telah ditelaah ini akan digunakan untuk mengidentifikasi kegiatan permainan outdoor dalam membentuk kemampuan ketahanmalangan anak usia dini. Penelitian studi literatur ini dilakukan dengan beberapa tahapan, yaitu (Efron \& Ravid, 2019) pada gambar 1.

\section{HASIL DAN PEMBAHASAN}

\section{Kemampuan Ketahanmalangan}

Konsep kemampuan ketahanmalangan bukan termasuk hal yang baru. Teori kemampuan ketahanmalangan dikemukakan oleh Stoltz yang memiliki arti, yaitu kemampuan yang dimiliki individu dalam mengamati kesulitan dan mengendalikan kesulitan tersebut. Hal ini yang dapat mengubah kesulitan menjadi tantangan yang dapat diselesaikan (Stoltz, 2000). Pendapat lain dari (Boonsamuan, 2016) yang mendefinisikan kemampuan ketahanmalangan merupakan kemampuan dalam mengatasi masalah dan memecahkan masalah. Kemampuan ini digunakan dalam membantu seorang individu memperkuat kemampuan kegigihan melalui tantangan hidup. Melalui kegigihan, individu dapat meraih kesuksesan dalam hidupnya.

Dalam pendapatnya Nelson dalam (Ahmad, 2013) memaparkan bahwa kemampuan ketahanmalangan merupakan kemampuan yang menggambarkan suatu ketahanan fisik, mental, spiritual untuk mengatasi perubahan yang cepat. Hal ini juga sejalan dengan pendapat Nashori yang menyebut bahwa kemampuan ketahanmalangan merupakan kemampuan individu dalam mengarahkan dan mengubah pikiran dan tindakannya, ketika individu menghadapi hambatan dan masalah (Napitupulu et al., 2007). Senada dengan pendapat Supardi yang menyatakan bahwa kemampuan ketahanmalangan merupakan keterampilan individu untuk menyelesaikan kesulitan yang terjadi dalam diri individu (Supardi U.S., 2015). Kemampuan ketahanmalangan juga memiliki dampak terhadap keberhasilan prestasi belajar anak. Anak yang memiliki kemampuan ketahanmalangan yang baik akan mampu mengatasi masalah dan kesulitan yang dihadapi.

Pendapat lain dari Shivaranjani yang menyatakakan bahwa kemampuan ketahanmalangan merupakan suatu kemampuan individu dalam menemukan ide dalam mengatasi kesulitan yang dialami yang berdampak dapat menimbulkan kestresan pada individu tersebut (Shivaranjini, 2014). Sejalan pendapat dari Sari, Sutopo dkk. yang menyatakan bahwa kemampuan ketahanmalangan merupakan kesanggupan individu dalam menghadapi tantangan dan masalah yang datang dalam kehidupannya (Sari et al., 2016). Pendapat lain dari Djafar, dkk menyatakan bahwa kemampuan ketahanmalangan merupakan suatu kemampuan dalam memegang kendali dan merespon suatu kesulitan atau tekanan secara positif (Djafar et al., 2018). Selanjutnya, Stoltz memaparkan kemampuan ketahanmalangan memiliki beberapa fungsi dalam kehidupan individu, seperti menggambarkan seberapa jauh individu mampu bertahan menghadapi dan mengatasi kesulitan, menggambarkan individu yang dapat menghadapi dan individu yang tidak dapat menghadapi kesulitan yang ada, dan menggambarkan individu yang akan menyerah dan siapa yang mampu mengatasi kesulitan yang ada (Stoltz, 2000).

Kemampuan ketahanmalangan terdiri dari empat dimensi, yaitu dapat terlihat pada anak yang dapat berhasil jika individu tersebut dapat mengendalikan diri, menempatkan diri secara wajar, tidak membesar-besarkan masalah yang sedang dihadapi, dan dapat berjuang mengahadapi permasalahan yang sedang terjadi dalam diri anak. Dimensi-dimensi tersebut berpengaruh terhadap keberhasilan pencapaian kemampuan ketahanmalangan. Kemampuan ketahanmalangan pada anak usia dini memiliki beberapa karakteristik, yaitu 
anak yang memiliki kegigihan, keuletan, motivasi yang tinggi, daya juang yang tinggi, ramah, mudah akrab dengan lingkungan, serta dapat berpikir kreatif dalam memecahkan permasalahan yang sedang dihadapi (Crie Handini \& Nur Hasanah, 2017). Hal ini sejalan dengan pendapat Michael yang menyatakan bahwa anak-anak seharusnya dilatih dan diajari dalam menghadapi tantangan kehidupan dengan rasa percaya diri dan keberanian dalam dirinya (Biddulp \& Kristiana D, 2005). Anak dilatih untuk berpikir bahwa kegagalan dan rintangan yang dihadapi bersifat sementara. Hal ini membuat anak tidak kehilangan rasa percaya diri yang positif mengenai mereka sendiri. Anak yang memiliki sikap percaya diri dan keberanian dalam diri akan mampu menghadapi dan memecahkan masalah ataupun hambatan yang dihadapi anak yang berdampak terhadap keberhasilan dan kesuksesan anak di masa depan.

Dengan demikian, dari pemaparan ahli di atas mengenai pengertian kemampuan ketahanmalangan dapat dideskripsikan bahwa kemampuan ketahanmalangan adalah kesanggupan individu dalam mengontrol emosi dan tindakan saat menghadapi kesulitan dan hambatan dalam kehidupannya yang mendorong individu tersebut mencapai kesuksesan dan keberhasilan hidup di masa depan.

\section{Permainan Outdoor}

Proses permainan outdoor merupakan proses yang harus terus dinegosiasikan dalam permainan anak-anak dan guru menjadikannya sebagai sebuah budaya. Kegiatan permainan outdoor memberikan pengaruh yang sangat penting pada anak. Hal ini dikarenakan ketika kehidupan anak-anak semakin diatur oleh orang dewasa anak-anak akan beralih dari lingkungan keluarga ke dalam struktur formal sistem pendidikan (Perry, 2001). Pengaturan bermain di luar ruangan mungkin menjadi satu tempat di mana anakanak dapat secara mandiri mengatur negosiasi mereka sendiri dengan lingkungan fisik dan sosial dan mendapatkan kejelasan kedirian yang diperlukan untuk menavigasi di kemudian hari.

Selanjutnya, manfaat permainan outdoor terhadap perkembangan anak diperkuat oleh hasil-hasil penelitian terlebih dahulu, seperti penelitian yang dilakukan oleh (McClintic \& Petty, 2015) yang memaparkan bahwa melalui pengalaman permainan outdoor dapat memberikan dampak positif terhadap perkembangan individu anak dan prilaku anak. Setiap orang membangun realitas mereka sebagai hasil dari pengalaman dan bagaimana mereka menafsirkan pengalaman-pengalaman itu. Hal ini yang membuat guru yakin bahwa permainan mempengaruhi tindakan dan perilaku anak. Penelitian lain yang dilakukan (Ceciliani \& Bortolotti, 2013) mengemukakan bahwa permainan outdoor memberikan manfaat terhadap perkembangan fisik dan perilaku anak. Fisik dan perilaku anak dapat berkembang secara optimal melalui permainan outdoor. Hal ini dikarenakan pada saat bermain outdoor memberikan pengalaman bermain yang bebas dan pengalaman bermain yang menyenangkan yang melibatkan keaktifan anak dalam mengembangkan kemampuan motoriknya dan berdampak juga terhadap keberanian, dan kepercayaan diri anak. Bermain di luar biasanya lebih banyak membutuhkan kekuatan dan lebih bersemangat, yang diharapkan dapat memberikan dampak positif terhadap keberhasilan aspek perkembangan anak. Hal ini seperti, yang dinyatakan (Maynard et al., 2014) bahwa permainan outdoor dapat memberikan kegiatan pembelajaran yang secara langsung dilakukan di alam terbuka dengan memanfaatkan alam sekitarnya sebagai media pembelajaran.

Kegiatan bermain di luar memberikan kontribusi penting bagi pertumbuhan dan kesejateraan anak baik dalam perkembangan fisik maupun dalam perkembangan mental dan emosional anak (Casey, 2007). Hal ini dapat dilihat dari sikap dan perilaku anak ketika bermain dengan teman anak dapat mengendalikan emosi saat anak kalah bermain dan tidak menangis. Sejalan dengan pendapat yang dipaparkan oleh (Vera, 2012) yang menyatakan bahwa permainan outdoor memberikan dorongan dalam pembentukan sikap dan mental anak. Selain itu, melaui permainan outdoor anak diberi kesempatan untuk merubah 
perilaku mereka menjadi ke arah yang positif. Bermain di luar ruangan masuk ke dalam kategori yang mendukung keterampilan motorik kasar, mendukung eksplorasi bebas lingkungan, dan mendukung penilaian dalam perilaku sikap keberanian (McFarland \& Laird, 2018). Anak yang memiliki keberanian dalam dirinya diharapkan dapat membantu kemampuan ketahanmalangan dalam diri anak. Salah satu kegiatan permainan outdoor yang memiliki dampak positif terhadap kemampuan ketahanmalangan anak, yaitu melalui kegiatan bermain outbound. Permainan outbound merupakan salah satu permainan yang dilakukan di luar kelas yang dapat meningkatkan kemampuan yang dimiliki oleh anak yang dilakukan melalui berbagai kegiatan yang menantang melalui media alam. Menurut (Rocmah, 2012) outbound adalah kegiatan di luar ruangan yang bersifat petualangan dan penuh tantangan sebagai proses pembelajaran untuk menemukenali potensi-potensi anak, sehingga anak dapat mengenali dirinya sendiri. Outbound sendiri memiliki tujuan, yaitu untuk mengembangkan sikap keterbukaan dan keberanian diri sambil menikmati alam bagi individu (Susari, 2016). Kesempatan dan kebebasan untuk melakukan bermacammacam kegiatan akan memberikan pengalaman baru bagi anak yang dapat membantu perkembangan anak. Kegiatan permainan outbound memiliki manfaat bagi anak, yaitu mendukung anak dalam berpikir kreatif, memberikan motivasi dalam diri anak, dapat berkomunikasi dengan baik, melatih kegigihan anak, mendukung anak mengembangkan inisiatif pribadi, memberikan pengaturan yang bermakna untuk pembentukan sikap anak dan membantu mewujudkan potensi masing-masing anak (Yudanto, 2012).

\section{Permainan Outdoor dalam membangun Kemampuan Ketahanmalangan Anak Usia Dini}

Moore dan Woong dalam (Azlina \& S., 2012) memaparkan bahwa permainan outdoor memberikan stimulasi terhadap aspek perkembangan anak. Dalam melakukan kegiatan permainan outdoor dapat memberikan anak kebebasan, kepetualangan, percaya diri dan kesempatan dalam memecahkan masalah yang termasuk kedalam dimensi kemampuan ketahanmalangan. Selanjutnya, melalui kegiatan permainan outdoor akan dapat mengurangi rasa takut pada anak (Beyer et al., 2015). Selain itu, melalui permainan outdoor menjadikan anak menjadi individu yang dapat mengontrol emosi pada dirinya dan menjadikan anak menjadi anak yang berpikir kreatif untuk mencoba hal baru yang terdapat dalam kegiatan (Shi, 2017). Selanjutnya, pendapat lain yang dipaparkan oleh (Acar, 2014) bahwa kegiatan permainan outdoor yang dilakukan oleh anak dapat memberikan peran penting terhadap perkembangan sikap berani dan percaya diri serta perkembangan pada ketahanan anak.

Selanjutnya, (Mulyasa, 2012) memaparkan bahwa permainan outdoor bukan hanya dapat mengembangkan kemampuan motorik kasar anak saja, melainkan dapat memberikan perkembangan terhadap kemampuan ketahanmalangan pada anak. hal ini dikarenakan pada saat melakukan kegiatan permainan outdoor akan membeikan anak pengalaman yang dapat membentuk sikap yang termasuk kemampuan ketahanmalangan, seperti sikap berani, tidak pantang menyerah dan menjadikan anak kreatif dalam menyelesaikan tantangan yang terdapat dalam kegiatan. Banyaknya kegiatan yang dapat dirancang di luar ruangan akan menarik perhatian anak yang menjadikan anak tidak pasif dan bosan saat melakukan kegiatan serta dapat menumbuhkan daya juang dalam diri anak (Hinkley et al., 2018).

Dengan demikian, dari pemaparan literatur review yang telah dipaparkan diatas, di simpulkan bahwa kegiatan permainan outdoor dapat membantu membentuk dan melatih kemampuan ketahanmalangan dalam diri anak. hal ini dikarenakan pada kegiatan permainan outdoor di dalamnya terdapat unsur-unsur kegiatan yang membentuk dimensi kemampuan ketahanmalangan dalam diri anak, seperti sikap berani, tidak mudah menyerah, memiliki kepercayaan diri yang tinggi dan dapat mengatasi serta menyelesaikan masalah-masalah yang di dihadapi oleh anak dalam kegiatan sehari-hari. 


\section{SIMPULAN}

Kemampuan ketahanmalangan merupakan kemampuan individu untuk dapat mengontrol emosi dan tindakan pada saat individu menghadapi kesulitan dan hambatan dalam kehidupannya. Kemampuan ketahanmalangan memiliki peran penting terhadap kesuksesan anak yang membuat kemampuan ketahanmalangan harus dilatih dan dibentuk sejak usia dini. Salah satu kegiatan yang dapat membantu perkembangan ketahanmalangan pada anak, yaitu kegiatan permainan outdoor. Hal ini dikarenakan dalam permainan outdoor memberikan kegiatan pembelajaran yang mengandung unsur kebebasan, keberanian, kepercaya dirian dan kepetualangan yang termasuk ke dalam dimensi kemampuan ketahanmalangan.

\section{UCAPAN TERIMA KASIH}

Penulis mengucapkan terima kasih kepada dosen pembimbing atas bimbingan dan dukungan dalam menyelesaikan penulisan artikel ini menjadi lebih baik dan penulis mengucapkan terima kasih kepada berbagai pihak yang telah mendukung dan membantu penyelesaian artikel ini.

\section{DAFTAR PUSTAKA}

Acar, H. (2014). Learning Environments for Children in Outdoor Spaces. Procedia - Social and Behavioral Sciences, 141, 846-853. https://doi.org/10.1016/j.sbspro.2014.05.147

Agama Kementrian. (2020). Petunjuk Teknis Penyelenggaraan Taman Pendidikan Al-Quran.

Ahmad, S. (2013). Ketahanmalangan kepemimpinan kepala sekolah. Pustaka Felicha.

Azlina, W., \& S., Z. A. (2012). A Pilot Study: The Impact of Outdoor Play Spaces on Kindergarten Children. Procedia - Social and Behavioral Sciences, 38, 275-283. https://doi.org/10.1016/j.sbspro.2012.03.349

Beyer, K., Bizub, J., Szabo, A., Heller, B., Kistner, A., Shawgo, E., \& Zetts, C. (2015). Development and validation of the attitudes toward outdoor play scales for children. Social Science and Medicine, 133, 253-260. https://doi.org/10.1016/j.socscimed.2014.10.033

Biddulp, M., \& Kristiana D, G. (2005). Meningkatkan kekuatan pikiran anak. Prestasi Pustaka Raya.

Blanchet-Cohen, N., \& Elliot, E. (2011). Young Children and Educators Engagement and Learning Outdoors: A Basis for Rights-Based Programming. Early Education and Development, 22(5), 757-777. https:/ / doi.org/10.1080/10409289.2011.596460

Boonsamuan, S. (2016). Affecting factors to improve adversity quotient in children through games-based learning. The International Conference on Digital Arts, Media and Technology, February.

Casey, T. (2007). Environments for outdoor play. SAGE.

Ceciliani, A., \& Bortolotti, A. (2013). Outdoor motor play: Analysis, speculations, research paths. CEPS Journal, 3(3), 65-86.

Crie Handini, M., \& Nur Hasanah, L. (2017). The Enhancement Adversity Quotient Through Outbound Play Activities. In Advances in Social Science, Education and Humanities Research (Vol. 8). https://doi.org/10.2991/icece-16.2017.58

Djafar, A., Noviekayati, I., \& Saragih, S. (2018). Perbedaan adversity quotient dan kematangan emosi remaja SMP ditinjau dari jenis kelamin. Journal Psikogenesis, 6(1), 61-68. https://doi.org/10.24854/jps.v6i1.633

Grotberg, E. (1995). A guide to promoting resilience in children: strengthening the human spirit. Early Childhood Development: Practice and Reflections. In Early Childhood Development: Practice and Reflections (Nomor 8). http://resilnet.uiuc.edu/library/grotb95b.html

Hinkley, T., Brown, H., Carson, V., \& Teychenne, M. (2018). Cross sectional associations of screen time and outdoor play with social skills in preschool children. PLOS ONE, 
13(4), e0193700. https://doi.org/10.1371/journal.pone.0193700.t004

Holifatur, R. R., \& Christiana, E. (2013). Studi tentang permasalahan sosial dan penanganannya pada anak usia dini kelompok A di Desa Torjun Kabupaten Sampang. BK Unesa, 4(1), 10-15.

Kuswanto, Wijaya, C. (2016). Menumbuhkan kemandirian anak usia dini melalui bermain. Ilmiah Pendidikan Islam Anak Usia Dini, 1(2), 20-34.

Maynard, Trisha, Waters, \& Jane. (2014). Exploring Outdoor Play In The Early Years. University Press. https:/ / books.google.com/books?id=0EqLBgAAQBAJ\&pgis=1

McClintic, S., \& Petty, K. (2015). Exploring Early Childhood Teachers' Beliefs and Practices About Preschool Outdoor Play: A Qualitative Study. Journal of Early Childhood Teacher Education, 36(1), 24-43. https://doi.org/10.1080/10901027.2014.997844

McFarland, L., \& Laird, S. G. (2018). Parents' and Early Childhood Educators' Attitudes and Practices in Relation to Children's Outdoor Risky Play. Early Childhood Education Journal, 46(2), 159-168. https://doi.org/10.1007/s10643-017-0856-8

Mulyasa, E. (2012). Manajemen Paud. In Manajemen PAUD. Remaja Rosdakarya.

Napitupulu, L., Nashori, F., \& Kurniawan, I. N. (2007). Pelatihan Adversity Intelligence Untuk Meningkatkan Kebermaknaan Hidup Remaja Panti Asuhan. Psikologika: Jurnal $\begin{array}{llll}\text { Pemikiran Penelitian } & \text { Psikologi, }\end{array}$ https:// doi.org/10.20885/psikologika.vol12.iss23.art4

Perry, J. (2001). Outdoor Play: Teaching Strategies With Young Children. Teachers Collage.

Rocmah, L. I. (2012). Model Pembelajaran Outbound Untuk Anak Usia Dini. PEDAGOGIA: Jurnal Pendidikan, 1(2), 173. https:// doi.org/10.21070/pedagogia.v1i2.40

Sari, C. K., Sutopo, S., \& Aryuna, D. R. (2016). The Profile of Students' Thinking in Solving Mathematics Problems Based on Adversity Quotient. JRAMathEdu (Journal of Research and Advances in Mathematics Education), 1(1), 36-48. https://doi.org/10.23917/jramathedu.v1i1.1784

Shi, Y. (2017). Explore Children's Outdoor Play Spaces of Community Areas in High-density Cities in China: Wuhan as an Example. Procedia Engineering, 198(September 2016), 654-682. https://doi.org/10.1016/j.proeng.2017.07.118

Shivaranjini. (2014). Adversity quotient: One stop solution to combat attrition rate of women in Indian IT sector. International Journal of Business and Administration Research Review, 1(5), 181-189.

Stoltz, P. G. (2000). Adversity Quotient: Mengubah Hambatan Menjadi Peluang. (Terjemahan T. Hermaya). In Jakarta: Gramedia Widiasarana Indonesia. Grasindo.

Supardi U.S., S. U. S. (2015). Pengaruh Adversity Qoutient terhadap Prestasi Belajar Matematika. Formatif: Jurnal Ilmiah Pendidikan MIPA, 3(1), 61-71. https://doi.org/10.30998/formatif.v3i1.112

Susari, H. D. (2016). Implementasi Kegiatan Outbound Dalam Upaya Pembentukan Perilaku Sosial Dan Emosional Anak Usia Dini. Premiere Educandum: Jurnal Pendidikan Dasar dan Pembelajaran, 1(02), 121-141. https://doi.org/10.25273/pe.v1i02.41

Sutapa, P., Wibawa, S., Kauki, M. K., Pratama, K. W., \& Mustapha, A. (2020). Development of gross motor ability in early childhood through playing mini outbound. Easy Chair preprints are intended for rapid dissemination of research results and are integrated with the rest of EasyChair (2020).

UNICEF. (2003). Life Skills: Definition of Terms. http://www.unicef.org/lifeskills/index_7308.html

Vera, A. (2012). Metode Mengajar Anak di Luar Kelas (Outdoor Study). Jogjakarta: DIVA Pres.

Woodrow, L., \& Woodrow, L. (2019). Writing the Literature Review. In Doing a Master's Dissertation in TESOL and Applied Linguistics. The Guilford Press. https://doi.org/10.4324/9780429504068-10

Yudanto. (2012). Outbound as one of The outdoor education in elementary school. Jurnal UNY. 